\title{
CARDIOVASCULAR, RENAL, AND GENERAL EFFECTS OF LARGE, RAPID PLASMA INFUSIONS IN CONVALESCENT MEN ${ }^{1}$
}

\author{
By JESSE R. WILSON, JR., ${ }^{2}$ AND CLINTON R. HARRISON 8 WITH THE TECHNICAI \\ ASSISTANCE OF LEONARD L. TAYLOR,4 CHARLES E. KNIGHT,4 \\ AND WILLIAM F. HAINES * \\ (From the United States Naval Medical Research Unit, Cairo, Egypt)
}

(Received for publication June 23, 1949)

Clinicians and investigators generally agree that fluid replacement in the treatment of shock due to blood loss should be rapid. It is common teaching, however, that intravenous fluids are best given slowly when shock is not being corrected.

In this study reconstituted human plasma was given rapidly by vein to 10 convalescent males in order to observe the cardiovascular, renal, and general effects on individuals with normal blood volumes. Amounts of plasma from 900-1955 cc. given in $51 / 2-60$ minutes were well tolerated.

\section{REVIEW OF LITERATURE}

There have been numerous studies of the effects of the intravenous injection of large amounts of fluids into animals (1-16) and into man (1725). Eyster and Middleton (17) found that injection of about $1 \%$ of body weight of blood in 10 14 minutes into cases of primary anemia caused transitory changes in blood and venous pressures and insignificant alterations in heart size. Caughey (18) gave cardiacs $1500 \mathrm{cc}$. of saline in $30 \mathrm{~min}$ utes, noting rise of venous pressure followed by a very slow fall, and failure of the venous pressure to subside quickly after infusion has been used by Richards, Caughey, et al. (19) as a test for heart failure. Gilligan et al. $(20,21)$ gave saline and/or glucose in varying concentrations in amounts up to $1500 \mathrm{cc}$. at rates up to $71 \mathrm{cc}$. per minute to sub-

1 The opinicns expressed in this paper are those of the authors and do not necessarily coincide with those of the Bureau of Medicine and Surgery of the U. S. Navy.

2 Lieutenant (jg), Medical Corps, United States Naval Reserve. Present address: Cincinnati General Hospital, Cincinnati, Ohio.

s Lieutenant (jg), Medical Corps, United States Naval Reserve. Present address: Department of Physiology, Johns Hopkins University School of Medicine, Baltimore, Maryland.

\& HMC, U.S.N. jects without cardiac disease and not in shock. They report blood volume increases, venous pressure rises, increased cardiac output, cutaneous dilatation, and inconstant changes in blood pressure, pulse, and respiration. Murphy et al. (22) gave normals and cardiacs rapid infusions of saline or varying concentrations of glucose in water with and without added aminophylline. Venous pressure and plasma volume rose together, falling with the onset of diuresis. Changes in blood pressure, pulse, and respiration were, as a rule, insignificant. Loutit et al. (23) gave 500-1000 cc. of blood at rates of $7-45 \mathrm{cc}$. per minute, observing rise of venous pressure in most cases. Sharpey-Schafer and Wallace $(24,25)$ report the largest, most rapid injections of fluid into subjects without cardiac disease. They gave normal saline or serum at rates up to $168 \mathrm{cc}$. per minute for $2000 \mathrm{cc}$. of saline, and up to $154 \mathrm{cc}$. per minute for $2100 \mathrm{cc}$. of serum. Rises of venous pressure up to 11.0 $\mathrm{cm}$. above resting levels were noted, with prompt fall after completion of the injection. Pulse changes were variable. Vital capacity decreased, and there was X-ray evidence of pulmonary vascular congestion and enlargement of the heart. Peripheral vasodilatation was noted. Urticaria occurred in four of 13 cases. Headache and a feeling of constriction in the chest were the only symptoms. Cargill (26) gave $300 \mathrm{cc}$. of $25 \%$ salt-poor albumin in 10-25 minutes to normal, hypertensive, and nephritic men and found an immediate fall in hematocrit, prompt increase in both inulin and para-aminohippurate clearances, and fall in filtered fraction and extraction ratio of paraaminohippurate.

\section{MATERIALS AND METHODS}

Ten native Egyptian males, ages 17 to 33, were studied. Each was convalescent from an infectious disease-typhoid fever in four instances. Six were distinctly small (see Table I). Four were anemic, one having a hemo- 
globin of 9.7 gms. All except Case 2 were afebrile at the time of the test.

Initial brachial blood pressure, pulse rate, respiratory rate, temperature, hematocrit, and blood volume measurements were made and an indwelling urethral catheter was inserted. Four and one-half gms. of creatinine (Pfanstiehl) and 3 cc. of $20 \%$ sodium para-aminohippurate (Sharp \& Dohme), referred to as $\mathrm{PAH}$, in about $50 \mathrm{cc}$. of normal saline were given intravenously in one to two minutes. This was immediately followed by a sustaining infusion of these substances. Plasma creatinine concentrations of 12-20 mgm. per $100 \mathrm{cc}$., and PAH concentrations of 1-3 mgm. per $100 \mathrm{cc}$. were maintained. A 40minute equilibration period was followed by three to four control clearance periods, during which the venous pressure baseline was established. A plasma infusion was then given rapidly through an 18 or 19 gage needle usually in an ankle vein. A saline bottle into which air pressure could be applied by means of a connection to a hand bulb was used as the infusion flask. Blood pressure, pulse, and venous pressure observations were made approximately every minute during and immediately following the infusion. The time used for the injection was considered as one clearance period. Subsequently, urine was collected at 10 or 15 minute intervals. The bladder was emptied by manual compression suprapubically and was rinsed three times with $10 \mathrm{cc}$. of saline and some air. Blood samples were taken every 30 minutes. Tests were continued for about two hours after the infusion. No renal studies were carried out in Cases 4 or 5 .

Blood pressure was measured indirectly with a Tycos aneroid sphygmomanometer. Venous pressure was determined directly through an 18 or 19 gage needle in the femoral vein of the leg not used for the infusion, employing a simple fluid manometer with $2 \frac{1}{2} \%$ sodium citrate as the balancing fluid. The zero point of the manometer was horizontal to a point approximately $5 \mathrm{~cm}$. dorsal to the second intercostal space at the sternum.

Hematocrits were determined by the method of Wintrobe (27), spinning the tubes for $\mathbf{4 5}$ minutes at 3000 RPM in a centrifuge with an effective radius of $14.5 \mathrm{~cm}$. At times, due to current fluctuations, the RPM fell below 3000 ; but as hematocrit determinations on a given subject were generally made simultaneously, values on an individual are comparable.

The procedure for determining creatinine has been described by Phillips et al. (28). Following Smith et al. (29), PAH was determined by applying the diazo method of Bratton and Marshall for the determination of free sulfanilamide (30). The $\mathrm{PAH}$ clearance, without an extraction correction factor, was used to measure changes in renal plasma flow. As facilities for inulin or mannitol clearances were not available, creatinine clearance was used as a reflection of glomerular filtration, although it is generally felt that inulin or mannitol better measure this in man $(31,32)$. Creatinine/inulin ratios recently published $(33,34)$ suggest, however, that creatinine clearance is a fairly good measure of glomerular filtration, especially when PAH or diodrast is administered concurrently.

The procedure of Phillips et al. (35) for estimating blood and plasma volume using the blue dye T-1824 was followed. A Coleman Junior Model 6A spectrophotometer was used for the creatinine, $\mathrm{PAH}$, and $\mathrm{T}-1824$ determinations.

\section{RESULTS}

The cardiovascular and general effects of the infusions are summarized in Table I.

All subjects tolerated the procedure well. Most of them exhibited considerable apprehension during the infusion but were calm, as a rule, be-

TABLE I

Cardiovascular and general effects of plasma infusions

\begin{tabular}{|c|c|c|c|c|c|c|c|c|c|c|c|c|c|c|c|c|c|c|c|c|c|}
\hline \multirow[b]{2}{*}{ Case } & \multirow[b]{2}{*}{ S.A.* } & \multirow[b]{2}{*}{ Wt. } & \multicolumn{2}{|c|}{$\begin{array}{l}\text { Plasma } \\
\text { infused }\end{array}$} & \multicolumn{2}{|c|}{ Blood volume } & \multicolumn{3}{|c|}{ Hematocrit } & \multicolumn{2}{|c|}{ Pulse } & \multicolumn{2}{|c|}{$\begin{array}{c}\text { Mean } \\
\text { blood } \\
\text { pressure }\end{array}$} & \multicolumn{2}{|c|}{$\begin{array}{l}\text { Venous } \\
\text { pressure }\end{array}$} & \multicolumn{2}{|c|}{$\begin{array}{l}\text { Respira- } \\
\text { tory rate }\end{array}$} & \multicolumn{2}{|c|}{ Temperature } & \multirow{2}{*}{\multicolumn{2}{|c|}{ 疍 总 }} \\
\hline & & & $\stackrel{\stackrel{\rightleftarrows}{E}}{4}$ & $\underset{\underline{E}}{\stackrel{g}{\underline{E}}}$ & 蛋 & 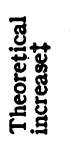 & 呇 & 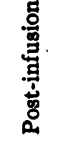 & 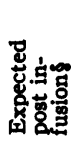 & 㞼 & 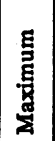 & 氶 & $\underset{\mathrm{E}}{\mathrm{E}}$ & 丞 & E & 矛 & 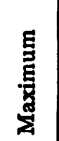 & 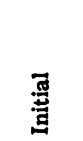 & 嘼 & & \\
\hline \begin{tabular}{r|}
1 \\
2 \\
3 \\
4 \\
5 \\
6 \\
7 \\
8 \\
9 \\
10
\end{tabular} & $\begin{array}{l}\text { sq.m. } \\
1.91 \\
1.40 \\
1.41 \\
1.59 \\
1.40 \\
1.73 \\
1.89 \\
1.50 \\
1.55 \\
1.80\end{array}$ & \begin{tabular}{|l|}
$k g$. \\
72.7 \\
47.5 \\
41.8 \\
50.4 \\
40.8 \\
61.4 \\
67.7 \\
50.4 \\
46.1 \\
60.9
\end{tabular} & \begin{tabular}{|c|}
$c c$. \\
975 \\
950 \\
950 \\
1955 \\
925 \\
1180 \\
1200 \\
1100 \\
900 \\
$1000+$
\end{tabular} & $\begin{array}{c}\min . \\
30 \\
22 \\
22 \\
60 \\
9 \\
93 \\
10 \frac{3}{2} \\
10 \\
13 \\
5 \\
10 \frac{3}{3}\end{array}$ & $\begin{array}{c}c c . \\
6700 \\
4540 \\
3580 \\
4450 \\
3510 \\
5460 \\
6250 \\
4030 \\
4060 \\
7330\end{array}$ & $\begin{array}{c}\% \\
14.6 \\
20.9 \\
26.5 \\
44.0 \\
26.4 \\
21.6 \\
19.2 \\
27.3 \\
22.2 \\
13.6\end{array}$ & $\begin{array}{l}\mathrm{mm} . \\
44.6 \\
33.8 \\
34.2 \\
37.1 \\
42.9 \\
49.9 \\
50.0 \\
51.3 \\
33.7 \\
50.7\end{array}$ & $\begin{array}{l}\mathrm{mm} . \\
39.4 \\
27.5 \\
25.8 \\
\overline{33.2} \\
\overline{40.0} \\
40.9 \\
28.5 \\
41.6\end{array}$ & $\begin{array}{l}m m . \\
38.9 \\
28.0 \\
27.0 \\
25.8 \\
34.0 \\
41.0 \\
41.9 \\
40.3 \\
27.6 \\
44.6\end{array}$ & $\begin{array}{c}\text { per } \\
\text { min. } \\
94 \\
94 \\
94 \\
84 \\
80 \\
68 \\
50 \\
64 \\
70 \\
60\end{array}$ & $\begin{array}{c}\text { per } \\
\text { min. } \\
-\overline{112} \\
116 \\
124 \\
148 \\
128 \\
128 \\
135 \\
144 \\
120\end{array}$ & $\begin{array}{c}m m_{g} \\
- \\
= \\
\overline{82} \\
90 \\
\frac{85}{101} \\
-\end{array}$ & $\begin{array}{l}\operatorname{mmg}_{H \boldsymbol{g}} \\
= \\
\overline{1} \\
108 \\
105 \\
\overline{110} \\
115 \\
=\end{array}$ & $\begin{array}{c}\text { cm. } \\
\text { cilrate } \\
- \\
= \\
\overline{9.0} \\
2.4 \\
1.5 \\
4.0 \\
5.0 \\
\overline{4.0}\end{array}$ & $\begin{array}{c}\text { cm. } \\
\text { citrate } \\
= \\
= \\
\overline{18.3} \\
17.0 \\
9.0 \\
17.0 \\
15.5 \\
\overline{15.0}\end{array}$ & $\begin{array}{c}\text { per } \\
\text { min. } \\
- \\
= \\
\overline{16} \\
20 \\
24 \\
20 \\
18 \\
\frac{18}{18}\end{array}$ & $\begin{array}{c}\text { per } \\
\text { min. } \\
= \\
= \\
20 \\
36 \\
24 \\
36 \\
24 \\
\frac{36}{36}\end{array}$ & $\begin{array}{c}\text { degrees } \\
F . \\
99.6 \\
101.0 \\
98.6 \\
99.8 \\
98.4 \\
99.0 \\
99.0 \\
97.6 \\
99.4 \\
98.6\end{array}$ & $\begin{array}{c}\text { degrees } \\
F . \\
100.2 \\
101.2 \\
98.8 \\
100.4 \\
104.2 \\
99.6 \\
101.0 \\
100.6 \\
99.6 \\
99.2\end{array}$ & $\begin{array}{l}\bar{z} \\
\bar{t} \\
+ \\
0 \\
0 \\
\frac{ \pm}{+}\end{array}$ & $\begin{array}{l}- \\
\overline{+} \\
+ \\
+ \\
+ \\
+\end{array}$ \\
\hline
\end{tabular}

$*$ S.A. $=\mathrm{Wt}^{0.425} \times \mathrm{Ht}^{0.725} \times 71.84$ (DuBois).

† Not measured accurately: $\pm 100 \mathrm{cc}$.

$\ddagger$ Per cent increase $=\frac{\text { Amt. Plasma Infused }}{\text { Initial Blood Volume }} \times 100$.
8 See text for method of calculation.

II Average of systolic and diastolic. 
TABLE II

Renal effects of plasma infusions

\begin{tabular}{|c|c|c|c|c|c|c|c|c|c|c|}
\hline \multirow{2}{*}{ Case } & \multicolumn{2}{|c|}{ Plasma infused } & \multicolumn{2}{|c|}{ Urine output } & \multicolumn{2}{|c|}{ Creatinine clearance } & \multicolumn{2}{|c|}{ PAH clearance } & \multicolumn{2}{|c|}{ Filtered fraction } \\
\hline & Amt. & Time & $\begin{array}{l}\text { Control } \\
\text { average }\end{array}$ & $\begin{array}{c}\text { Max. after } \\
\text { plasma }\end{array}$ & $\begin{array}{l}\text { Control } \\
\text { average }\end{array}$ & $\begin{array}{l}\text { Max. after } \\
\text { plasma }\end{array}$ & $\begin{array}{l}\text { Control } \\
\text { average }\end{array}$ & $\begin{array}{l}\text { Max. after } \\
\text { plasma }\end{array}$ & $\begin{array}{l}\text { Control } \\
\text { average }\end{array}$ & $\begin{array}{c}\text { Max. after } \\
\text { plasma }\end{array}$ \\
\hline $\begin{array}{r}1 * \\
2 \\
3 \\
6 \\
7 \\
8 \\
9 \\
10\end{array}$ & $\begin{array}{c}c c . \\
975 \\
950 \\
950 \\
1180 \\
1200 \\
1100 \\
900 \\
1000 \dagger\end{array}$ & $\begin{array}{l}\min . \\
30 \\
22 \frac{1}{2} \\
22 \frac{1}{2} \\
10 \frac{1}{2} \\
10 \\
13 \frac{1}{2} \\
5 \frac{1}{2} \\
10 \frac{1}{2}\end{array}$ & $\begin{array}{l}\text { cc. per mix. } \\
3.1 \\
1.5 \\
2.6 \\
1.3 \\
0.95 \\
1.4 \\
2.3 \\
3.7\end{array}$ & $\begin{array}{c}\text { cc. per min. } \\
2.8 \\
6.6 \\
6.6 \\
9.4 \\
14.1 \\
7.3 \\
14.4 \\
18.9\end{array}$ & $\begin{array}{c}\text { cc. per mix. } \\
178 \\
160 \\
129 \\
124 \\
175 \\
184 \\
167 \\
169\end{array}$ & $\begin{array}{l}\text { cc. per min. } \\
180 \\
208 \ddagger \\
125 \\
352 \\
269 \\
248 \\
184 \\
384\end{array}$ & $\begin{array}{c}\text { cc. per min. } \\
625 \\
731 \\
508 \\
442 \\
657 \\
661 \\
470 \\
648\end{array}$ & $\begin{array}{c}\text { cc. per min. } \\
860 \\
1001 \\
600 \\
1450 \\
1370 \\
1103 \\
918 \\
1555\end{array}$ & $\begin{array}{l}.28 \\
.22 \\
.25 \\
.28 \\
.27 \\
.28 \\
.36 \\
.26\end{array}$ & $\begin{array}{l}.21 \\
.19 \\
.20 \\
.24 \\
.17 \\
.21 \\
.20 \\
.18\end{array}$ \\
\hline
\end{tabular}

* Followed only 33 minutes after plasma.

$\dagger$ Not measured accurately; $\pm 100 \mathrm{cc}$.

$\ddagger$ Sudden rise in last period measured; perhaps due to technical error.

fore and after the injection. Three complained of a peculiar taste, one of tightness in the chest, and one of pain in the abdomen. Respiratory rate rose markedly in three cases. Cough was prominent in two. Several had chills, and three showed late temperature rises of more than $1^{\circ} \mathrm{F}$. Six subjects developed blue urticaria within an hour after the infusions, while the remaining four were not examined for its presence. In two cases the urticaria covered large portions of the trunk and thighs and to a lesser extent the face. The blue color was undoubtedly due to the T-1824.

The hematocrit fell in each instance. The expected falls, calculated from the relation,

\section{$H=\frac{\text { Initial Blood Volume } \times \text { Initial Hematocrit }}{\text { Initial Blood Volume }+ \text { Volume of Plasma Infused }}$,}

where $H$ is the expected post-infusion hematocrit, agreed fairly closely with the measured post-infusion hematocrits, indicating that the blood volume was augmented in each instance by approximately the amount of plasma infused. The blood volumes were increased from $13.6-44.0 \%$.

The pulse rate, mean blood pressure, and venous pressure rose sharply with the infusion in every case, usually reaching maximum values at about the time of completion of the injection. Return toward normal values began very quickly after completion of the infusion, but the rate of fall toward normal decreased after the first few minutes. The pulse rate was slower in subsiding than was venous pressure, while blood pressure fell to normal almost immediately. The blood pressure changes included a diastolic rise approximately equal to the systolic rise. In two instances the major diastolic increase preceded the major systolic increase.

The effects on renal function are presented in Table II. In Cases 6-10, who received plasma rapidly ( $5 \frac{1}{2}-13 \frac{1}{2}$ minutes), the infusion was followed by rises in creatinine and PAH clearances, the increases over control levels averaging $123 \mathrm{cc}$. and $703 \mathrm{cc}$. per minute respectively. The peaks of clearances usually occurred about $25 \mathrm{~min}$ utes after infusion and were generally followed in 15-20 minutes by the peaks of the diureses, which averaged $10.9 \mathrm{cc}$. per minute increase above control rates of urine flow.

In Cases 1-3, who received plasma more slowly (221/2-30 minutes), a rise in creatinine clearance occurred only in Case 2. This rise appeared suddenly about $3 / 4$ hour after the infusion and may have been due to a technical error. A rise in PAH clearance occurred in all three cases. The average rise was $199 \mathrm{cc}$. per minute. A diuresis was noted in Cases 2 and 3.

In Cases 1, 7, and 10 both clearances were briefly depressed immediately. after the infusions and prior to rising sharply. In Case 2 the PAH but not the creatinine clearance was temporarily decreased, while in Case 9 only the creatinine clearance was thus depressed. In three cases a secondary rise in PAH clearance occurred, in two coincidentally with a rise in temperature. In all other cases both clearances fell to or near normal in about one hour.

The filtered fraction (as represented by the creatinine clearance/PAH clearance ratio) was 


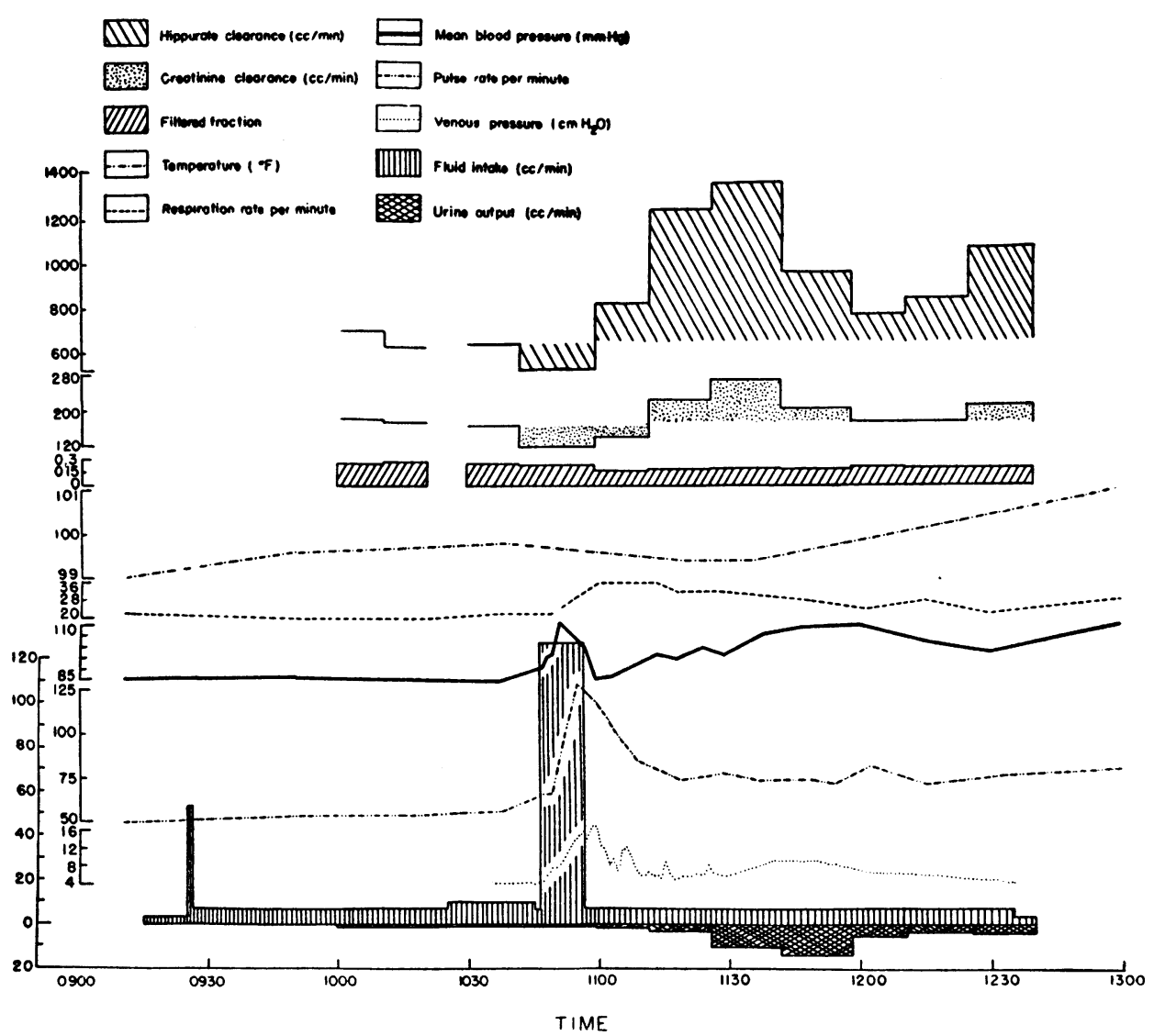

Fig. 1. Effects of Infusion of 1200 cc. of Plasma in 10 Minutes in Case 7

See text for explanation.

invariably and immediately decreased by the injection and returned slowly toward normal.

The results obtained in Case 7 are, in general, typical (see Figure 1). This patient was given $1200 \mathrm{cc}$. plasma in 10 minutes. He tolerated it well although he exhibited apprehension during the procedure. His blood pressure, pulse rate, respiratory rate, and venous pressure all rose and fell characteristically. Atypically, the mean blood pressure showed a secondary rise coincident with a rise in temperature to $101^{\circ} \mathrm{F}$. The diuresis described the usual pattern, and both clearances rose and subsided in typical fashion after an initial depression. A secondary increase in clearances accompanied the rise in temperature. The filtered fraction fell following the infusion and then rose slowly, not reaching normal while observed.

\section{DISCUSSION}

It appears from this work and that of SharpeySchafer and Wallace (24) that the danger of caus- ing cardiac embarrassment and pulmonary edema by rapid injection of large amounts of colloid solutions into individuals free from cardiac or pulmonary disease is not great. Although suddenly increasing the blood volume caused sharp rises in venous pressure, as has been repeatedly demonstrated by others both in animals $(1,2,4,8,10$, $13,16)$ and in man $(17,21-24)$, venous pressure levels did not exceed $20-30 \mathrm{~cm} . \mathrm{H}_{2} \mathrm{O}$, above which, at least in dogs, the ventricles cannot respond by increase in cardiac output $(3,7,13)$.

Increase in pulse rate can be accounted for on the basis of great vein or auricular distension (4), although anxiety may have contributed to the rises. Pulse rate and blood pressure changes similar to ours have been noted by several investigators after large infusions into dogs $(1,2,4,13)$. Others have found slight or inconstant changes in dog (15) and in man $(17,22-24)$, possibly because of lower rates of fluid administration $(17,22,23)$ 
or because of failure to measure pulse rate and blood pressure during infusion $(15,23,24)$.

The prompt falls in blood pressure and venous pressure after completion of the injections undoubtedly resulted from a generalized vasodilatation to accomodate the augmented blood volume. Such a vasodilatation occurred in the kidney, where the great increases in $\mathrm{PAH}$ clearance are interpreted as reflecting increase in renal plasma flow.

Recently Cargill (26) has pointed out that under some conditions PAH clearance alone may be an inaccurate measure of renal plasma flow in man, for he found that the extraction ratio of $\mathrm{PAH}$ fell after infusions of large amounts of concentrated serum albumin. An increase in $\mathrm{PAH}$ clearance with a falling extraction ratio, however, can only mean that renal blood flow is increased.

The immediate brief drops in clearances observed in some of our cases may have been caused by: (1) increased renal venous pressure, which has been clearly shown by Bradley and Bradley (36) to cause decreased glomerular filtration and decreased renal blood flow; (2) anxiety, with splanchnic vasoconstriction; (3) sudden changes in the blood levels of the clearance substances; (4) presence of substances in the plasma which temporarily partially blocked filtration of creatinine and tubular excretion of PAH. Either of the first two mechanisms was probably operative. The third is unlikely because the falls in clearances were out of proportion to the observed changes in creatinine and $\mathrm{PAH}$ plasma levels. We have no information to support or deny the fourth explanation.

We have no satisfactory explanation for the later disproportionate changes in $\mathrm{PAH}$ and creatinine clearances, resulting in decreased filtered fraction values. Intraglomerular pressure changes may have been taking place. Such changes in filtered fraction were also noted by Cargill (26) after infusing albumin, but Lauson et al. (37) recorded increased filtered fraction when patients in shock were transfused.

The major renal responses to suddenly increased blood volume were; then, vasodilatation followed by diuresis. A later return to a normal renal vasomotor state is indicated by a fall of the clearances toward normal in about one hour.

The presence of pyrogens in the plasma we in- fused is suggested by the frequent chills and the large late temperature rises in three cases. It is well known that pyrogens can cause increase in renal blood flow (38). The initial large rises in our cases, however, occurred probably too quickly to be attributed to pyrogens, although the later secondary rises in clearances observed in three instances might well be due to them.

The occurrence of urticaria after therapeutic infusion of plasma, albumin, or blood is relatively uncommon (39-48). Instances of its occurrence have been related to supposed or proved allergens in the fluid administered. We cannot explain the high incidence of urticaria noted by us and by others $(11,25)$. Sharpey-Schafer and Wallace (25) suggest that the urticaria represents a generalized loss to the tissues of the excess intravascular fluid. Whether such is merely a mechanical process or whether there is localized damage to capillaries by substances in the plasma we cannot say. The latter seems more likely.

\section{SUMMARY}

1. Infusions of from 900-1955 cc. of reconstituted human plasma were given in $51 / 2-60 \mathrm{~min}$ utes to 10 convalescent males and were well tolerated.

2. Sudden increase in blood volume was accompanied by a temporary increase in pulse rate, respiratory rate, blood pressure and venous pressure, and a fall in hematocrit.

3. Creatinine and para-aminohippurate clearances rose sharply and fell slowly and were accompanied by a diuresis. In some cases there was an initial depression of one or both clearances prior to the large rises. The filtered fraction fell in all cases, and then rose slowly.

4. Adjustments of the cardiovascular and renal systems to large, sudden increments in blood volume are discussed.

\section{ACKNOWLEDGMENT}

The authors wish to thank Dr. Franklin A. Neva for assistance in some of the tests and Dr. Robert A. Phillips for help in interpreting our results.

\section{BIBLIOGRAPHY}

1. Conheim, and Lichtheim, Ueber hydraemie und hydraemisches Oedem. Virchows Arch. f. Path. Anat., 1877, 96, 106, cited by (2). 
2. Bayliss, W. M., and Starling, E. H., Observations on venous pressures and their relationship to capillary pressure. J. Physiol., 1894, 16, 159.

3. Patterson, S. W., and Starling, E. H., On the mechanical factors which determine the output of the ventricles. J. Physiol., 1914, 48, 357.

4. Bainbridge, F. A., The influence of venous filling upon the rate of the heart. J. Physiol., 1915, 50, 65.

5. Smith, A. H., and Mendel, L. B., The adjustment of blood volume after injection of isotonic solutions of varied composition. Am. J. Physiol., 1920, 53, 323.

6. White, H. L., and Erlanger, J., The effect on the composition of the blood of maintaining an increased blood volume by the intravenous injection of a hypertonic solution of gum acacia and glucose in normal, asphyxiated and shocked dogs. Am. J. Physiol., 1920, 54, 1.

7. Wiggers, C. J., and Katz, L. N., The contour of the ventricular volume curves under different conditions. Am. J. Physiol., 1922, 58, 439.

8. Meek, W. J., and Eyster, J. A. E., The effect of plethora and variations in venous pressure on diastolic size and output of the heart. Am. J. Physiol., 1922, 61, 186.

9. Eyster, J. A. E., Experimental and clinical studies in cardiac hypertrophy. J. A. M. A., 1928, 91, 1881.

10. Harrison, T. R., Harrison, W. G., Jr., and Marsh, J. P., Reflex stimulation of respiration from increase in venous pressure. Am. J. Physiol., 1932, $100,417$.

11. Freeman, N. E., and Wallace, W. M., The effect of concentrated serum on plasma volume and serum protein concentration. Am. J. Physiol., 1938, 124, 791.

12. Ashworth, C. T., Muirhead, E. E., and Hill, J. M., The effect of hypertonic plasma on the body fluids in normal experimental animals. Am. J. Physiol., 1942, 136, 194.

13. Yeomans, A., Porter, R. R., and Swank, R. L., Observations on certain manifestations of circulatory congestion produced in dogs by rapid infusion. $\mathrm{J}$. Clin. Invest., 1943, 22, 33.

14. Metcalf, W., The fate and effects of transfused serum or plasma in normal dogs. J. Clin. Invest., 1944, 23, 403.

15. Holt, J. P., and Knoefel, P. K., Changes in plasma volume and cardiac output following the intravenous injection of gelatin, serum, and physiological saline solution. J. Clin. Invest., 1944, 23, 657.

16. Landis, E. M., Brown, E., Fauteux, M., and Wise, C., Central venous pressure in relation to cardiac "competence," blood volume and exercise. J. Clin. Invest., 1946, 25, 237.

17. Eyster, J. A. E., and Middleton, W. S., Cardiovascular reactions to hemorrhage and transfusion in man. Am. J. Physiol., 1924, 68, 581.

18. Caughey, J. L., Jr., Effect of rapid infusion on venous pressure: a test of cardiac reserve. Proc. Soc. Exper. Biol. \& Med., 1935, 32, 973.
19. Richards, D. W., Jr., Caughey, J. L., Cournand, A., and Chamberlain, F. L., Intravenous saline infusion as clinical test for right-heart and left-heart failure. Tr. A. Am. Physicians, 1937, 52, 250.

20. Gilligan, D. R., Altschule, M. D., and Volk, M. C., The effects on the cardiovascular system of fluids administered intravenously in man. I. Studies of the amount and duration of changes in blood volume. J. Clin. Invest., 1938, 17, 7.

21. Altschule, M. D., and Gilligan, D. R., Effects on the cardiovascular system of fluids administered intravenously in man. II. The dynamics of the circulation. J. Clin. Invest., 1938, 17, 401.

22. Murphy, F. D., Correll, H., and Grill, J. C., The effects of intravenous solutions on patients with and without cardiovascular defects. J. A. M. A., 1941, 116, 104.

23. Loutit, J. F., Mollison, M. D., and van der Walt, E. D., Venous pressure during venesection and blood transfusion. Brit. M. J., 1942, 2, 658.

24. Sharpey-Schafer, E. P., and Wallace, J., Circulatory overloading following rapid intravenous injections. Brit. M. J., 1942, 2, 304.

25. Sharpey-Schafer, E. P., and Wallace, J., Retention of injected serum in the circulation. Lancet, 1942, 1, 699.

26. Cargill, W. H., Effect of the intravenous administration of human serum albumin on renal function. Proc. Soc. Exper. Biol. \& Med., 1948, 68, 189.

27. Wintrobe, M. M., Macroscopic examination of the blood. Am. J. M. Sc., 1933, 185, 58.

28. Phillips, R. A., Dole, V. P., Hamilton, P. B., Emerson, K., Jr., Archibald, R. M., and Van Slyke, D. D., Effects of acute hemorrhag:c and traumatic shock on renal function of dogs. Am. J. Physiol., 1946, 145, 314.

29. Smith, H. W., Finkelstein, N., Aliminosa, L., Crawford, B., and Graber, M., The renal clearances of substituted hippuric acid derivatives and other aromatic acids in dog and man. J. Clin. Invest., 1945, 24, 388.

30. Bratton, A. C., and Marshall, E. K., Jr., A new coupling component for sulfanilamide determination. J. Biol. Chem., 1939, 128, 537.

31. Shannon, J. A., The renal excretion of creatinine in man. J. Clin. Invest., 1935, 14, 403.

32. Shannon, J. A., and Ranges, H. A., On the renal tubular excretion of creatinine in normal man. J. Clin. Invest., 1941, 20, 169.

33. Hare, K., Goldstein, H., Barnett, H. L., McNamara, H., and Hare, R. S., Renal excretion of creatinine in man. Federation Proc., 1949, 8, 67.

34. Crawford, B., Depression of the exogenous creatinine/ inulin or thiosulfate clearance ratios in man by diodrast and $p$-aminohippuric acid. J. Clin. Invest., 1948, 27, 171.

35. Phillips, R. A., Yeomans, A., Dole, V. P., Farr, L. E., and Van Slyke, D. D., Estimation of blood volume from change in blood specific gravity following a plasma infusion. J. Clin. Invest., 1946, 25, 261. 
36. Bradley, S. E., and Bradley, G. P., The effect of increased intraabdominal pressure on renal function in man. J. Clin. Invest., 1947, 26, 1010.

37. Lauson, H. D., Bradley, S. E., and Cournand, A., The renal circulation in shock. J. Clin. Invest., 1944, 23, 381.

38. Smith, H. W., Lectures on the Kidney. University Extension Division, University of Kansas, Lawrence, Kansas, 1943.

39. Stewart, W., and Bates, T., Urticaria during blood transfusion. Lancet, 1938, 1, 319.

40. DeGowin, E. L., Hardin, R. C., and Swanson, L. W., Studies on preserved human blood. IV. Transfusion of cold blood into man. J. A. M. A., 1940, $114,859$.

41. DeGowin, E. L., and Hardin, R. C., Studies on preserved human blood. VI. Reactions from transfusion. J. A. M. A., 1940, 115, 895.

42. Clegg, J. W., and Dible, J. H., Preparation and use of human serum for blood-transfusion in shock. Lancet, 1940, 2, 294.

43. Hill, J. M., Muirhead, E. E., Ashworth, C. T., and
Tigertt, W. D., The use of desiccated plasma. J. A. M. A., 1941, 116, 395.

44. Erf, L. A., and Jones, H. W., Experiences associated with a transfusion unit in a 700 bed hospital; an annual survey of over 3500 administrations of blood and plasma (dried). Ann. Int. Med., 1943, $19,1$.

45. Downs, T. M., A reaction to dried pooled human plasma. U. S. Nav. M. Bull., 1943, 41, 189.

46. Lozner, E. L., and Newhouser, L. R., Preservation of normal human plasma in the liquid state. I. A statistical study of 1751 administrations. J. Clin. Invest., 1944, 23, 343.

47. Janeway, C. A., Gibson, S. T., Woodruff, L. M., Heyl, J. T., Bailey, O. T., and Newhouser, L. R., Chemical, clinical, and immunological studies on the products of human plasma fractionation. VII. Concentrated human serum albumin. J. Clin. Invest., 1944, 23, 465.

48. Maunsell, K., Urticarial reactions and desensitization in allergic recipients after serum transfusions. Brit. M. J., 1944, 2, 236. 